All the forces of the enormous German potash propaganda had been at work for many years in directing as far as possible all search for American potash to the far western regions from which the freight alone across the country would nearly equal the prices at which Germany could lay down potash on our eastern seaboard, and, as was proved by the Schmidtman contracts above referred to, at an enormous profit to German mines if allowed to operate on large production.

The widespread feldspar and greensand potash deposits of the East were prevented from exploitation by the secret forces of the same propaganda frightening proverbially timid capital away from the enormous investments required in plants and machinery for operation of necessary processes to change this insoluble potash to soluble form.

The hidden deposits of soluble potash that must of necessity exist in the salt fields of the eastern United States could not be accidentally discovered as they had been by hundreds of years of shaft and stope mining for rock salt in the salt fields of Germany, for the very good reason that salt mining in the United States has been entirely developed in the last seventy-five years and confined entirely to the purest veins of sodium salt, where there could not of course be any potash, and this same propaganda exploited to the fullest extent the idea that an all-wise Providerice had confined potash deposits to the German salt fields alone.

The European war embargo on German potash therefore found this country totally unprepared to develop quickly any potash production within the limits to which capital could be obtained, except in the salt lakes and deserts of the far West, and only the high prices obtainable justified the costly work of recovery on the comparatively small scale permitted by the limited capital which could be interested. No man who invested a dollar in potash plants during the war period was ever sure of having six months in which to operate without being again subjected to German competition. Consequently investments were made as far as possible with the idea of getting in and getting out quickly with a profit if possible.

After three or four years' record of reasonable profits, some companies actually did get economical operations established, so that with reasonable protection afforded, they can even now produce potash salts at less than double the old German prices.

The exploitation of the several processes for extraction of the insoluble feldspar and greensand potash in the East has gone on slowly and steadily as capital could be secured, and with the protection afforded by the bill in question one plant now almost completed and several more under way will get into operation and will not be hampered by heavy freight from western deposits.

If the present bill had been a law any time before or during the war, American potash production would in less than five years have been on such a scale of magnitude that prices far lower than even the Schmidtman contracts would give handsome profits.

It is a fact well proved by history that whenever American manufacturers are sure of no competition which can have any advantages of foreign cheap labor or foreign government protection, they go into the intensive development of a product on large-scale production with labor-saving mechanical ingenuity that always results in cheapening of that product to a point where foreign competition is left far behind.

With the passage of the bill in question it is a foregone conclusion that capital will be ready and eager to go forward with the developments now so well under way, and in a very short time American quantity production, with the results of the wonderful research work that has been carried out by American chemists for the past five years, will totally destroy Germany's domination of the potash industry of the world. Without this protection, the industry is doomed and German domination will be permanent and complete.

Notwithstanding the fact that the recent German and French potash contracts have been made with American fertilizer companies (three of the principal companies still own large interests in German potash mines), at about the old price (\$37.00 per ton of 80 per cent muriate), the price charged the good old American farmer is $\$ 52.00$ per ton or only a little below the price at which American producers were already offering their American-made potash.

The actual difference to the farmer, therefore, will be but very few dollars and the profit will go to the importer who is sending good American dollars out of this country, instead of to the American mine and factory whose every expense benefits the sadly unemployed ranks of American labor and brains.

136 LIBERTY ST.

H. D. RUHM

NEW YORK, N. Y.

January 20,1922

\section{Fire at Heyden Chemical Plant}

Editor of the Journal of Industrial and Engineering Chemistry:

We have noted in the January issue of the JourNaL a statement with reference to our fire which is grossly exaggerated.

The plant of the Heyden Chemical Company of America, Inc., Garfield, N. J., was visited by a serious fire on the afternoon of December 12, in the refined salicylic acid section. The fire loss, including use and occupancy insurance, is estimated to be between $\$ 550,000$ and $\$ 600,000$.

The conflagration started at $2: 45 \mathrm{P}$. M. in the middle sublimer of a set of three. Two employees were cleaning the hot air chamber. One of them left the chamber and upon returning tripped over a flexible extension cord connected with a properly protected electric light bulb. The lamp fell to the iron grating at the bottom of the hot air chamber, knocking off the guard and breaking the bulb, and the terminal wires came in contact with the iron which caused a short-circuit. The flash ignited the refined salicylic acid in the chamber. The operators endeavored to put out the fire with buckets of water, which failed, and they then closed all dampers, enclosing the flame in the hot air chamber. The sides of the chamber were bulged out by the gas generated from this small fire, which caused the flame to spread instantly to the dust in the room and then to the salicylic acid which had just been removed from the sublimer. The company's fire department had a hose stream playing on the burning sublimer at about the time the dust ignited, which caused a "puff," blowing out the end wall of the building, and the wind carried the flames around the fire protection walls, separating each of the sublimers, and the other sublimers caught fire, causing the destruction of the refined section of the salicylic acid, sodium salicylate and acetylsalicylic acid departments.

The capacity of the destroyed refined salicylic acid section of the plant was approximately $225,000 \mathrm{lbs}$. of U. S. P. acid per month. The crude equipment is intact.

Of the five men who were burned, four of them have reported back at work and the fifth, the foreman who was most seriously burned, it is expected will be discharged from the hospital early in February. The foreman, who was the most seriously burned, received his injuries through his efforts to turn on the valve con-. trolling the carbon dioxide gas, with which all sublimers were equipped to prevent the possibility of serious fire. $\mathrm{He}$ was caught in the "puff" which took place just as he was entering the sublimer room.

\section{F. H. Chamberlain, President}

Heipden Chemical Company of America, ine. GaRfield, N. J. January 18,1922 